\title{
Thermodynamic Studies on the Interaction between Phenylalanine with Some Divalent Metal Ions in Water and Water-Dioxane Mixtures
}

\author{
Ebrahim Ghiamati* and Samieh Oliaei \\ Chemistry Department, University of Birjand, P.O. Box 414, Birjand, South Khorasan, Iran
}

Received: 30 January, 2017; Accepted: 06 February, 2017; Published: 13 February, 2017

*Corresponding author: Ebrahim Ghiamati, Chemistry Department, University of Birjand, P.O. Box 414, Birjand, South Khorasan, Iran, Fax : +98 563220 2515, Tel : +98 915-715-5364,E-mail : eghiamati@birjand.ac.ir

\begin{abstract}
A new and simple method was developed to determine the stability constants of phenylalanine complexes of $\mathrm{Co}$ (II), Ni (II), Cu(II), $\mathrm{Zn}$ (II) and $\mathrm{Pb}$ (II) metal ions in water and water-dioxane mixtures at four different temperatures of $25,37,45$ and $55^{\circ} \mathrm{C}$ potentiometrically using modified Bjerrum method. Ionic strength of medium was retained at $0.10 \mathrm{M}$ by sodium nitrate. Our results revealed that the stability constant values are greater in water-dioxane mixtures than in water alone. The increasing trend in stability constant values in water and mixture of water-dioxane are the same as follows:

$$
\mathrm{K}_{\mathrm{fCo} \text { (II)-Phe }}<\mathrm{K}_{\mathrm{fZn} \text { (II)- Phe }}<\mathrm{K}_{\mathrm{fpb} \text { (II)-Phe }}<\mathrm{K}_{\mathrm{fN} \text { (II)-Phe }}<\mathrm{K}_{\mathrm{fCu} \text { (II) }}{ }^{- \text {Phe }}
$$

Furthermore, by knowing the stability constants at different temperatures, thermodynamic parameters of $\Delta \mathrm{H}^{\circ}, \Delta \mathrm{S}^{\circ}$ and $\Delta \mathrm{G}^{\circ}$ for the respective complexes were acquired. $\Delta \mathrm{H}^{\circ}, \Delta \mathrm{S}^{\circ}$ values were positive. Negative $\Delta G^{\circ}$ values conveyed the spontaneity of the complex formation process. Also it is found out that the stability constant of the pertinent complexes increases as the temperature rises meaning that the reactions are endothermic.
\end{abstract}

Keywords: Stability constant, Amino acid complex, Potentiometric titrations, Thermodynamic parameters.

\section{Introduction}

The amino acids have special importance among the other chemical groups since they are building block of proteins. The interactions between metal ions and amino acids have attracted the attention of many biochemists, because they can be used as a model for metal-protein reactions mimicking metal-enzyme mechanism. The explanation of these phenomena in the biological systems requires the determination of the stability constants as a measure of how well the complex of the amino acids with various metal ions in a medium similar to those of biological systems forms.

Among various methods for determining stability constants of complexes, potentiometry has its own advantages. Potentiometric titration of amino acids in the presents of metal ions is generally used as a method for measuring metal complex stability constants. This technique first described by Bjerrum [1] and has been investigated extensively by numerous researches [2-7]. D.J. Perkins examined amino acid structures on the stabilities of complexes formed with metals of group II [8]. A. E. Martell and coworkers have conducted vital studies on amino acid complexes and predicted their stability constants [9-11].

The behavior of the complexes at different temperatures was probed by M.S. Masoud et al. [12]. Thermodynamic parameters for the formation of glycine with metal ions were investigated by S. Sammartano [13]. Formations of binary and ternary complexes were studied by M.M. Shoukry et al. [14]. Cu (II) amino acids complexes are useful antibacterial agents [15]. The stability constants of copper (II) complexes with several amino acids were calculated in dioxane-water mixtures by A. Dogan et al. [16].

The stability of binary complexes of L-aspartic acid in dioxanewater mixture was probed by R.S. Rani et al. [17]. H. Demirelli, et al. have determined the formation constants of phenylalanine complexes of $\mathrm{Ni}(\mathrm{II}), \mathrm{Cu}(\mathrm{II})$, and $\mathrm{Zn}(\mathrm{II})$ in water media at $25^{\circ} \mathrm{C}$ and $\mu=0.1 \mathrm{~mol} \mathrm{~L}^{-1} \mathrm{KCl}$ [18]. A.A. Mohamed et al. [19] have measured stability constants and thermodynamic parameters for glycine and L-threonine complexes with some rare metal ions in water. The interactions of L- glutamic and L-aspartic acid with some metal ions has been probed by S.A.A Sajadi [20]. Critical survey of formation constants of phenylalanine with metal ions has been reported by L.D. Pettit [21]. A. Eid Fazary, et al. have investigated the protonation equilibria of $\alpha$ - amino acids in water and dioxane mixtures [22]. The stability constants of Ni (II) with some amino acids were probed by N. Turkel [23].

Phenylalanine is a one of the few amino acids that can directly affect brain chemistry by crossing the blood-brain barrier. Phenylalanine is used to cure depression, attention deficithyperactivity disorder (ADHD), Parkinson's disease, chronic pain, osteoarthritis, rheumatoid arthritis, alcohol withdrawal symptoms, and a skin disease called vitiligo [24]. 
In this work, the stability constants of phenylalanine complexes of some divalent metal ions in water and waterdioxane mixtures at four different temperatures have been evaluated. In addition thermodynamic parameters of pertinent complexes have been determined.

\section{Experimental Section}

\section{a. Materials and procedure}

Phenylalanine with purity of $99 \%$, the nitrate salts of Co(II), $\mathrm{Cu}(\mathrm{II}), \mathrm{Zn}(\mathrm{II}), \mathrm{Ni}(\mathrm{II})$ and $\mathrm{Pb}(\mathrm{II})$ (all pro-analysis), nitric acid $\left(\mathrm{HNO}_{3}\right)$, sodium hydroxide $(\mathrm{NaOH})$, hydrochloric acid $(\mathrm{HCl})$, perchloric acid $\left(\mathrm{HClO}_{4}\right)$ and sodium nitrate $\left(\mathrm{NaNO}_{3}\right)$ all were purchased from Merck and used as received. Deionized water was employed in all of the experiments. The $\mathrm{pH}$ potentiometric titrations were performed using Schott $\mathrm{pH}$ meter, Thermostat MLW16, glass cell, digital burette, and magnetic stirrer.

A special glass vessel (reactor) for potentiometric titrations was made which had a double wall with entries for combined glass electrode, nitrogen, and base from burette. Temperature inside the reactor was kept constant through circulation of water with an accuracy of $\pm 0.1^{\circ} \mathrm{C}$. A $25.00 \mathrm{~mL}$ solution mixture prepared so that it was $5.000 \times 10^{-3} \mathrm{M}$ with respect to phenylalanine, $3.000 \times 10^{-3} \mathrm{M}$ with respect to the respective metal ions and $1.690 \times 10^{-2} \mathrm{M}$ with respect to $\mathrm{HClO}_{4}$. A sufficient amount of $0.10 \mathrm{M} \mathrm{NaNO}_{3}$ was added to adjust the ionic strength. The solution was thermostatted to desired temperatures of $25,37,45$ and $55^{\circ} \mathrm{C}$ and then titrated with an accurately standardized $\mathrm{NaOH}$ solution while the titrand constantly was purged. The $\mathrm{pH}$ was recorded after each addition of titrant in $0.050 \mathrm{~mL}$ increments. The two electrodes used for measuring $\mathrm{pH}$ were glass electrode and calomel electrode. The pH meter was calibrated using Merck standard buffer solutions with $\mathrm{pH}$ of $4.0,7.0$ and 9.0.

\section{b. Calibration of the Glass Electrode}

Calibration of the combined glass electrode and calomel electrode was performed in both acidic and alkaline regions by titrating a solution of $0.01 \mathrm{molL}^{-1}$ hydrochloric acid with standard sodium hydroxide prior to each titration to read the hydrogen ion concentration directly. The emf values (E) depend on $\left[\mathrm{H}^{+}\right]$ according to $\mathrm{E}=\mathrm{E}_{0}+\operatorname{slog}\left[\mathrm{H}^{+}\right]+\mathrm{J}_{\mathrm{H}}\left[\mathrm{H}^{+}\right]+\mathrm{J}_{\mathrm{OH}}\left[\mathrm{OH}^{-}\right]$where $\mathrm{J}_{\mathrm{H}}$ and $\mathrm{J}_{\mathrm{OH}}$ are fitting parameters in acidic and alkaline media in order to correct experimental errors. These errors arise mainly from the liquid junction and the alkaline and acidic errors of the glass electrode [25].

c. The Method for determination of stability constant

The Bjerrum's pH titration procedure assumes the presence of the reacting species $\mathrm{H}_{2} \mathrm{~L}^{+}$as amino acid, $\mathrm{HL}$ as the monoprotonated amino acid, and $\mathrm{L}$

The anion of amino acid

$$
\begin{aligned}
& \mathrm{H}_{2} \mathrm{~L}^{+}=\mathrm{HL}_{(\mathrm{aq})}+\mathrm{H}_{(\mathrm{aq})}^{+} \\
& \mathrm{K}_{\mathrm{a}_{1}}=\frac{[\mathrm{HL}]\left[\mathrm{H}^{+}\right]}{\left[\mathrm{H}_{2} \mathrm{~L}^{+}\right]}
\end{aligned}
$$

$$
\begin{aligned}
& \mathrm{HL}_{(\mathrm{aq})} \rightleftharpoons \mathrm{L}_{(\mathrm{aq})}^{-}+\mathrm{H}_{(\mathrm{aq})}^{+} \\
& \mathrm{K}_{\mathrm{a}_{2}}=\frac{\left[\mathrm{L}^{-}\right]\left[\mathrm{H}^{+}\right]}{[\mathrm{HL}]} \\
& \mathrm{M}^{2+}+\mathrm{HL} \rightleftharpoons \mathrm{ML}^{+}+\mathrm{H}^{+} \\
& \mathrm{K}_{\mathrm{f} 1}=\frac{\left[\mathrm{ML}^{+}\right]\left[\mathrm{H}^{+}\right]}{\left[\mathrm{M}^{2+}\right]\left[\mathrm{HL}^{+}\right]} \\
& \mathrm{ML}^{+}+\mathrm{L}^{-}=\mathrm{ML}_{2} \\
& \mathrm{~K}_{\mathrm{f} 2}=\frac{\left[\mathrm{ML}_{2}\right]}{\left[\mathrm{ML}^{+}\right]\left[\mathrm{L}^{-}\right]}
\end{aligned}
$$

Here $K_{\mathrm{f} 1}$ and $\mathrm{K}_{\mathrm{f} 2}$ is the first and the second stability constants of the complexes. We define ${ }^{\bar{n}}$ as:

$$
\overline{\mathrm{n}}=\frac{\# \text { of bond ligands }}{\text { total metal ion concentration }}=\frac{\mathrm{L}_{\text {bound }}}{\mathrm{C}_{\mathrm{M}}}=\frac{\mathrm{L}_{\text {total }}-\mathrm{L}_{\text {free }}}{\mathrm{C}_{\mathrm{M}}}
$$

The concentration of free ligand is the sum of concentration of contained ligand species at different form, i.e.

$$
\mathrm{L}_{\text {free }}=\left[\mathrm{H}_{2} \mathrm{~L}\right]+[\mathrm{HL}]+\left[\mathrm{L}^{-}\right]
$$

The bound ligand concentration $\left(\mathrm{L}_{\text {bound }}\right)$ could then be estimated as:

$$
\mathrm{L}_{\text {bound }}=\mathrm{L}_{\text {total }}-\mathrm{L}_{\text {free }}
$$

After rearrangement and substitutions we have:

$$
\bar{n}=\frac{\mathrm{T}_{\mathrm{H}_{2} \mathrm{~L}^{+}}-\left[\mathrm{H}_{2} \mathrm{~L}^{+}\right]-[\mathrm{HL}]-\left[\mathrm{L}^{-}\right]}{\mathrm{T}_{\mathrm{M}^{2+}}}
$$

Then: $\overline{\mathrm{n}}=\frac{\left[\mathrm{ML}^{+}\right]+2\left[\mathrm{ML}_{2}\right]}{\left[\mathrm{M}^{2+}\right]+\left[\mathrm{ML}^{+}\right]+\left[\mathrm{ML}_{2}\right]}$

According to mass balance relation we have:

$$
\begin{aligned}
& \mathrm{T}_{\mathrm{M}}=\left[\mathrm{M}^{2+}\right]+\left[\mathrm{ML}^{+}\right]+\left[\mathrm{ML}_{2}\right] \\
& \mathrm{T}_{\mathrm{HL}}=[\mathrm{HL}]+\left[\mathrm{L}^{-}\right]+\left[\mathrm{ML}^{+}\right]+2\left[\mathrm{ML}_{2}\right]
\end{aligned}
$$




$$
\left[\mathrm{ClO}_{4}^{-}\right]=\mathrm{T}_{\mathrm{HClO} 4}+2 \mathrm{~T}_{\mathrm{M}}
$$

$\left[\mathrm{ML}^{+}\right]+2\left[\mathrm{ML}_{2}\right]=\left[\mathrm{Na}^{+}\right]-\mathrm{T}_{\mathrm{HClO}_{4}}+\left[\mathrm{H}^{+}\right]$

$$
\begin{aligned}
& \overline{\mathrm{n}}=\frac{\left[\mathrm{Na}^{+}\right]-\left[\mathrm{HClO}_{4}\right]+\left[\mathrm{H}^{+}\right]}{\mathrm{T}_{\mathrm{M}}} \\
& {[\mathrm{HL}]=\frac{\mathrm{K}_{\mathrm{a}}\left(\mathrm{T}_{\mathrm{H}_{2} \mathrm{~L}^{+}}-\overline{\mathrm{nT}_{\mathrm{M}}}\right)}{\mathrm{k}_{\mathrm{a}}+\left[\mathrm{H}^{+}\right]}}
\end{aligned}
$$

From plot of $\mathrm{p}_{\mathrm{HL}}$ versus ${ }^{\bar{n}}$ the stability constants could be calculated.

$$
\begin{aligned}
& \mathrm{K}_{\mathrm{f} 1}=\frac{1}{[\mathrm{HL}]_{\bar{n}=\frac{1}{2}}} \\
& \mathrm{~K}_{\mathrm{f} 2}=\frac{1}{[\mathrm{HL}]_{\overline{\mathrm{n}}=\frac{3}{2}}}
\end{aligned}
$$

All our calculations in this work were executed by GRCßeta computer-program developed in our lab. The software asks for a) initial volume of solution containing the amino acid, metal ion, and perchloric acid, b) the concentration of perchloric acid, c) the concentration of sodium hydroxide, d) the concentration of amino acid, and e) $\mathrm{pKa}_{1}$ and $\mathrm{pKa}_{2}$ of the amino acid in the specified medium and at desired ionic strength which we found them in literature. After insertion of the pertinent values, the software plots calculated $\mathrm{pH}$ ( corrected $\mathrm{pH}$ ) of the titrand solution versus the concentration of added standardized $\mathrm{NaOH}$, plus drawing two curves, one for a $\bar{n}=0.5$ and the other for $\bar{n}^{2}=1.5$. The intersection of the potentiometric titration curve with these two curves produces two points (Figure 1) whose corresponding pHs will be used to evaluate the respective stability constants of the metallic ion-amino acid complexes. Additionally the software

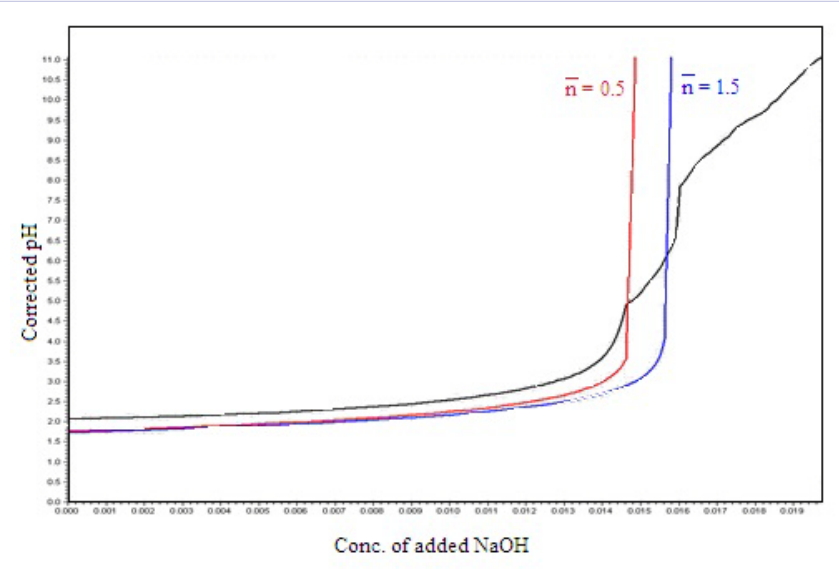

Figure 1: Plot of $\mathrm{pH}$ versus concentration of added standardized $\mathrm{NaOH}$ for $\mathrm{Cu}(\mathrm{II})$-Phe complex in (70-30) \% water - dioxane mixture solution at $25^{\circ} \mathrm{C}$ is capable of plotting first and second derivative of $\mathrm{d}$-pH versus $\mathrm{d}-\mathrm{V}_{\mathrm{NAOH}}$ to clarify the end points. For each potentiometric titration approximately 4-7 $\mathrm{mL}$ of standardized sodium hydroxide was used.

Thermodynamic calculations were conducted as follows:

The Gibb's free energy change, $\Delta G^{\circ}$, can be calculated from the equation below:

$$
\begin{gathered}
\Delta \mathrm{G}^{0}=-\mathrm{RT} \ln \mathrm{K}_{\mathrm{f}} \\
\ln \mathrm{K}_{\mathrm{f}}=\frac{-\Delta \mathrm{G}^{0}}{\mathrm{RT}}
\end{gathered}
$$

By taking the derivative with respect to $1 / \mathrm{T}$ from both side of equation (23) we have:

$$
\frac{\mathrm{d} \ln \mathrm{K}_{\mathrm{f}}}{\mathrm{d} \frac{1}{\mathrm{~T}}}=-\frac{1}{\mathrm{R}}\left\{\frac{\mathrm{d}}{\mathrm{d} \frac{1}{\mathrm{~T}}} \frac{\Delta \mathrm{G}^{0}}{\mathrm{~T}}\right\}
$$

$$
\begin{aligned}
& \frac{d \ln K_{f}}{d \frac{1}{T}}=-\frac{1}{R}\left\{\Delta G^{0}+\frac{d \Delta G^{0}}{T d \frac{1}{T}}\right\} \\
& \frac{d \ln K_{f}}{d \frac{1}{T}}=-\frac{1}{R}\left\{\Delta H^{o}-T \Delta S^{o}+T \Delta S^{o}\right\}=-\frac{\Delta H}{R}
\end{aligned}
$$

So: $\frac{\mathrm{d} \log \mathrm{K}_{\mathrm{f}}}{\mathrm{d} \frac{1}{\mathrm{~T}}}=-\frac{\Delta \mathrm{H}^{0}}{2.303 \mathrm{R}}$

Regarding equation (27), the plot of $\log K_{f}$ versus $1 / T$ produces straight line with slop equals:

$$
\text { slope }=\frac{-\Delta \mathrm{H}^{0}}{2.303 \mathrm{R}}
$$

Using Equation (28) enables us to calculate Enthalpy change. For calculating $\Delta \mathrm{S}^{0}$ we have:

$$
\Delta \mathrm{G}^{0}=\Delta \mathrm{H}^{0}-\mathrm{T} \Delta \mathrm{S}^{0}
$$

Knowing Gibbs free energy and enthalpy changes we can evaluate $\Delta S^{0}$

$$
\Delta \mathrm{S}^{0}=\frac{\Delta \mathrm{H}^{0}-\Delta \mathrm{G}^{0}}{\mathrm{~T}}
$$

\section{Results and Discussion}

As an example, the output of the software as demonstrated in Figure 1 is a plot of $\mathrm{pH}$ versus concentration of added standardized $\mathrm{NaOH}$ for $\mathrm{Cu}$ (II)-Phe complex in aqueous solution. Figure 2 illustrates the potentiometric titration curves of phenylalanine 
complexes with respective metal ions. As it is cleared, with increasing the stability of the complex, titration curve for $\mathrm{Cu}$ (II) inclines more toward the right. Table 1 represents the stability constants values of the phenylalanine complexes of Co (II), Ni (II), $\mathrm{Cu}$ (II), $\mathrm{Zn}$ (II) and $\mathrm{Pb}$ (II) in temperatures of $25,37,45$ and $55^{\circ} \mathrm{C}$ in aqueous solution. The stability constants of the complexes in $70-30 \%(\mathrm{v} / \mathrm{v})$ water-dioxane mixture have been shown in Table 2 . The results indicate that the order of increasing stability constants in both media are the same and as follows:

$$
\mathrm{K}_{\mathrm{fCO}(\mathrm{II})-\mathrm{Phe}}<\mathrm{K}_{\mathrm{fZn} \text { (II)- } \text { - } h e}<\mathrm{K}_{\mathrm{fPb} \text { (II)- Phe }}<\mathrm{K}_{\mathrm{fNi} \text { (II)- Phe }}<\mathrm{K}_{\mathrm{fCu} \text { (II) }}{ }^{-} \text {Phe }
$$

This stability trend is in agreement with Irving-William series [26], which is based on ionic potential of metallic ions. The more charge density, the more electrostatic forces appear between ligand and metallic ion causing an increase in stability constant (except $\mathrm{Cu}^{+2}$ ). Also the stability constant of complexes is related to their stabilization energies. $\mathrm{Cu}^{+2}$ with $\mathrm{d}^{9}$ configuration has the highest stability energy (Jahan-Teller effect) and $\mathrm{Co}^{+2}$ possesses the lowest stability energy among the first transition series. $\mathrm{Pb}^{+2}$ is located in fourth period and its stability constant cannot be compared with the others.

Potentiometric titration curves for $\mathrm{Cu}$ (II)-Phe complexes

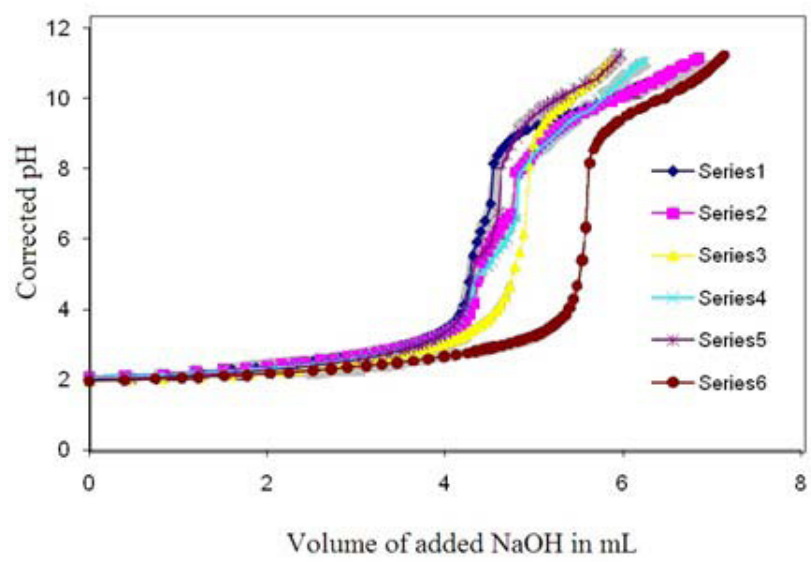

Figure 2: Potentiometric titration curves for the respective complexes at $25^{\circ} \mathrm{C}$ in water solution; series 1 : free of metal ions, series 2: Co (II) ions, series 3: $\mathrm{Zn}$ (II) ions, series 4: $\mathrm{Ni}$ (II) ions, series 5: $\mathrm{Pb}$ (II) ions and series 6: $\mathrm{Cu}$ (II) ions.

Table 1: The Log of the stability constants values for the respective metal ion-Phe complexes in aqueous solution at four different temperatures

\begin{tabular}{|c|c|c|c|c|c|}
\hline Complex & $\begin{array}{c}\text { Stability } \\
\text { constants }\end{array}$ & $25^{\circ} \mathrm{C}$ & $37^{\circ} \mathrm{C}$ & $45^{\circ} \mathrm{C}$ & $55^{\circ} \mathrm{C}$ \\
\hline $\begin{array}{l}\text { Co(II)- } \\
\text { Phe }\end{array}$ & $\begin{array}{l}\log k_{1} \\
\log k_{2}\end{array}$ & $\begin{array}{l}4.22 \\
3.61\end{array}$ & $\begin{array}{l}4.38 \\
3.78\end{array}$ & $\begin{array}{l}4.56 \\
3.94\end{array}$ & 4.784 .18 \\
\hline $\begin{array}{l}\text { Ni(II)- } \\
\text { Phe }\end{array}$ & $\begin{array}{l}\log k_{1} \\
\log k_{2}\end{array}$ & $\begin{array}{l}5.80 \\
4.17\end{array}$ & 5.944 .39 & 6.16452 & $\begin{array}{l}6.27 \\
4.82 \\
\end{array}$ \\
\hline $\begin{array}{l}\mathrm{Cu}(\mathrm{II})- \\
\text { Phe }\end{array}$ & $\begin{array}{l}\log k_{1} \\
\log k_{2}\end{array}$ & $\begin{array}{l}7.57 \\
6.21\end{array}$ & $\begin{array}{l}7.72 \\
6.28\end{array}$ & $\begin{array}{l}7.81 \\
6.38\end{array}$ & $\begin{array}{l}7.91 \\
6.93\end{array}$ \\
\hline $\begin{array}{l}\text { Zn(II)- } \\
\text { Phe }\end{array}$ & $\begin{array}{l}\log k_{1} \\
\log k_{2}\end{array}$ & 4.614 .56 & $\begin{array}{l}5.51 \\
4.75\end{array}$ & 6.125 .40 & $\begin{array}{l}6.20 \\
5.53\end{array}$ \\
\hline $\begin{array}{l}\mathrm{Pb}(\mathrm{II})- \\
\text { Phe }\end{array}$ & $\begin{array}{l}\log k_{1} \\
\log k_{2}\end{array}$ & $\begin{array}{l}5.69 \\
3.56\end{array}$ & $\begin{array}{l}5.89 \\
4.28\end{array}$ & 7.214 .89 & $\begin{array}{l}7.48 \\
5.11\end{array}$ \\
\hline
\end{tabular}

Table 2: The Log of stability constants values for the respective ion metal-Phe complexes in 70-30 \% (v/v) water- dioxane mixture at different temperatures

\begin{tabular}{|c|c|c|c|c|c|}
\hline Complex & $\begin{array}{c}\text { Stability } \\
\text { constants }\end{array}$ & $25^{\circ} \mathrm{C}$ & $37^{\circ} \mathrm{C}$ & $45^{\circ} \mathrm{C}$ & $55^{\circ} \mathrm{C}$ \\
\hline $\begin{array}{l}\text { Co(II)- } \\
\text { Phe }\end{array}$ & $\begin{array}{l}\log k_{1} \\
\log k_{2}\end{array}$ & $\begin{array}{l}4.80 \\
3.88\end{array}$ & $\begin{array}{l}4.95 \\
3.97\end{array}$ & $\begin{array}{l}5.12 \\
4.18\end{array}$ & $\begin{array}{l}5.28 \\
4.33\end{array}$ \\
\hline $\begin{array}{l}\text { Ni(II)- } \\
\text { Phe }\end{array}$ & $\begin{array}{l}\log k_{1} \\
\log k_{2}\end{array}$ & $\begin{array}{l}6.32 \\
5.20\end{array}$ & $\begin{array}{l}6.37 \\
5.32\end{array}$ & $\begin{array}{l}6.56 \\
5.50\end{array}$ & $\begin{array}{l}6.73 \\
5.65\end{array}$ \\
\hline $\begin{array}{l}\mathrm{Cu}(\mathrm{II})- \\
\text { Phe }\end{array}$ & $\begin{array}{l}\log k_{1} \\
\log k_{2}\end{array}$ & $\begin{array}{l}7.96 \\
6.43\end{array}$ & $\begin{array}{l}8.18 \\
6.81\end{array}$ & $\begin{array}{l}8.38 \\
7.38\end{array}$ & $\begin{array}{l}8.94 \\
7.67\end{array}$ \\
\hline $\begin{array}{l}\text { Zn(II)- } \\
\text { Phe }\end{array}$ & $\begin{array}{l}\operatorname{LogK}_{\mathrm{f} 1} \\
\log _{2}\end{array}$ & $\begin{array}{l}5.80 \\
5.75\end{array}$ & $\begin{array}{l}5.82 \\
5.86\end{array}$ & $\begin{array}{l}5.87 \\
5.93\end{array}$ & $\begin{array}{l}5.89 \\
6.01\end{array}$ \\
\hline $\begin{array}{l}\mathrm{Pb}(\mathrm{II})- \\
\text { Phe }\end{array}$ & $\begin{array}{l}\log k_{1} \\
\log k_{2}\end{array}$ & $\begin{array}{l}6.07 \\
5.76\end{array}$ & $\begin{array}{l}6.18 \\
5.82\end{array}$ & $\begin{array}{l}6.23 \\
5.95\end{array}$ & $\begin{array}{l}6.46 \\
6.04\end{array}$ \\
\hline
\end{tabular}

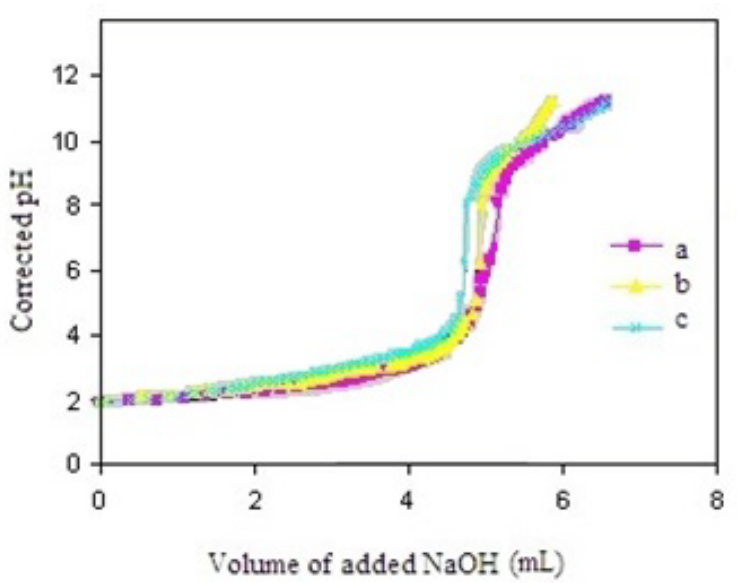

Figure 3: Potentiometric titration curves for Cu (II)-Phe complex at $25^{\circ} \mathrm{C}$ in a- $50-50 \%$ water-dioxane, b- $70-30 \%$ water-dioxane, c-water alone

for $50-50 \%, 70-30 \%(\mathrm{v} / \mathrm{v})$ and water alone have been shown in Figure 3. The more increase in the stability constant of a complex, the more its titration curve is drawn to the right. This means higher stability constant causes more $\mathrm{H}^{+}$to be released at lower pH. By changing the solvent, the acidity and basicity of solute varies. The acidic and basic dissociation constant of any species will be measured with respect to the solvent. If a solvent with dissociation constant value of less than water is used, the acidic property of that species increases, therefore the shape of titration curve inclines toward the lower $\mathrm{pH}$ with respect to water as solvent.

With increasing the percent of dioxane, the stability constant increases. Because the dissociation constant of amine group of phenylalanine is lower in dioxane than water, so, the stability constant should decrease. This statement is in contrast with the above results. The discrepancy can be explained by solvating 
ability of $\mathrm{ML}_{2}$ molecular species, which have more solvating ability in an organic solvent than in water. This is due to lower dielectric constant of dioxane, 2.3 with respect to water, 80 . Instead, the solvating ability of $\mathrm{M}^{+2}$ molecular ion species is higher in aqueous solution than in organic solvent. It can be expected that the stability constant values are greater in aqueous-organic mixture than in aqueous alone.

The thermodynamic parameters values in Tables 3 and 4 indicate that change in enthalpy for water and water-dioxane mixtures are positive, showing the reactions endothermocity. In all complex reactions with metal ions, the Gibb's free energy changes are negative referring to the reactions spontaneity. The trend has the same pattern for the formation of the complexes in water and in water-dioxane mixtures. It is worthy to note that on increase in the dioxane contents, the free energy becomes more negative, which is an evidence for increasing the stability of the respective complexes.

\section{Conclusions}

The stability constants of some divalent metal ion-Phe complexes in water, $70-30 \%$ and $50-50 \%(\mathrm{v} / \mathrm{v})$ water-dioxane

Table 3: Thermodynamic parameters for the pertinent metal ion - Phe complexes in water at $25^{\circ} \mathrm{C}$

\begin{tabular}{|c|c|c|c|}
\hline Complex & $\Delta \mathrm{H}^{\circ}{ }_{1}(\mathrm{KJ} / \mathrm{mol})$ & $\Delta \mathrm{S}^{\circ}{ }_{1}(\mathrm{~J} / \mathrm{K})$ & $-\Delta \mathrm{G}^{\circ}{ }_{1}(\mathrm{KJ} / \mathrm{mol})$ \\
\hline Co(II)-Phe & 6.16 & 99.2 & 23.4 \\
\hline $\mathrm{Ni}(\mathrm{II})-\mathrm{Phe}$ & 26.7 & 198.6 & 32.5 \\
\hline $\mathrm{Cu}(\mathrm{II})$ - Phe & 49.2 & 306.4 & 42.1 \\
\hline $\mathrm{Zn}(\mathrm{II})-\mathrm{Phe}$ & 44.85 & 269.2 & 35.4 \\
\hline $\mathrm{Pb}(\mathrm{II})-\mathrm{Phe}$ & 6.91 & 100.3 & 23.0 \\
\hline
\end{tabular}

Table 4: Thermodynamic parameters for the pertinent metal ion- Phe complexes in water dioxane mixture at $25^{\circ} \mathrm{C}$

\begin{tabular}{|c|c|c|c|c|c|c|}
\hline Complex & \multicolumn{3}{|c|}{$\begin{array}{c}\mathbf{7 0 - 3 0 \%} \text { v/v)water- } \\
\text { dioxane }\end{array}$} & \multicolumn{3}{|c|}{$\begin{array}{c}\mathbf{5 0 - 5 0 \% v / v ) w a t e r - ~} \\
\text { dioxane }\end{array}$} \\
\hline & $\Delta \mathrm{H}^{\circ}$ & $\Delta \mathrm{S}_{1}^{\circ}$ & $-\Delta \mathrm{G}_{1}^{\circ}$ & $\Delta \mathrm{H}_{1}^{\circ}$ & $\Delta \mathrm{S}^{\circ}{ }_{1}$ & $-\Delta \mathrm{G}^{\circ}{ }_{1}$ \\
\hline $\mathrm{Co}(\mathrm{II})-\mathrm{Phe}$ & 20.2 & 162.6 & 28.2 & 12.5 & 137.7 & 28.5 \\
\hline $\mathrm{Ni}(\mathrm{II})-\mathrm{Phe}$ & 19.1 & 177.1 & 33.7 & 16.8 & 170.6 & 34.1 \\
\hline $\mathrm{Cu}(\mathrm{II})-\mathrm{Phe}$ & 16.8 & 213.5 & 46.8 & 18.3 & 220.3 & 47.4 \\
\hline $\mathrm{Zn}(\mathrm{II})-\mathrm{Phe}$ & 55.4 & 307.0 & 36.1 & 12.5 & 173.7 & 39.3 \\
\hline $\mathrm{Pb}(\mathrm{II})-\mathrm{Phe}$ & 9.90 & 125.3 & 27.4 & 12.1 & 134.6 & 28.0 \\
\hline
\end{tabular}

Table 5: Comparison of the stability constants values for the pertinent metal ion- Phe complexes in water at $25^{\circ} \mathrm{C}$ in or Lab and in the literature

\begin{tabular}{|l|l|l|l|l|l|}
\hline Cation & $\mathbf{C o}^{2+}$ & $\mathbf{N i}^{2+}$ & $\mathbf{C u}^{2+}$ & $\mathbf{Z n}^{2+}$ & $\mathbf{P b}^{2+}$ \\
\hline $\log \beta$ & $\log \beta_{1,} \log \beta_{2}$ & $\log \beta_{1,} \log \beta_{2}$ & $\log \beta_{1,}, \lambda \circ \beta_{2}$ & $\log \beta_{1,}, \lambda o \gamma \beta_{2}$ & $\log \beta_{1,}, \lambda o \gamma \beta_{2}$ \\
\hline $\begin{array}{l}\text { Acquired in } \\
\text { our Lab }\end{array}$ & $4.22,7.83$ & $5.80,9.97$ & $7.57,13.78$ & $4.61,9.17$ & $5.69,9.25$ \\
\hline $\begin{array}{l}\text { The } \\
\text { literature[21] }\end{array}$ & $4.08,8.08$ & $5.46,9.99$ & $7.51,14.25$ & $4.80,9.11$ & $4.03,8.79$ \\
\hline
\end{tabular}

mixtures have been determined. The results indicate that the least stable complex is Co (II)-Phe and the most stable one is $\mathrm{Cu}$ (II)-Phe. As the percentage of dioxane in the solvent mixture increases, the stability of complexes rises too. This is due to a decrease in dielectric constant of water with respect to dioxane. In fact, co-solvent could affect the protonation-deprotonation equilibria in solution. This will happen by change in dielectric constant of the medium, which alters the relative contribution of electrostatic and non-eletrostatic interactions. Furthermore, thermodynamics parameters of $\Delta \mathrm{H}^{\circ}, \Delta \mathrm{S}^{\circ}$ and $\Delta \mathrm{G}^{\circ}$ were calculated. The data shows that the enthalpy change is positive for all the complexes indicating the reactions are endothermic. The negative $\Delta G^{\circ}$ values for all complexes gives an evidence for spontaneity of the complex reactions.

\section{Acknowledgement}

We wish to thank the University of Birjand research council for the finantioal support.

\section{References}

1. Bjerrum J. Metal-Ammine Formation in Aqueous Solution. Copenhagen, Denmark: P. Haase and Son. 1941;296p.

2. NormanCL, Doody EJM, WhiteE. Copper (II), nickel and uranyl complexes of some amino acids. J. Am. Chem. Soc. 1958;80(22):59015903.

3. Rossotti H. Chemical Applications of Potentiometry. N.J. Van Nostrand. 1969.

4. Rosenberg B, Sigel H, Marcel D. in Marzilli LG (Ed.) Metal Ions in Biological Systems. Wiley-Interscience, New York. 1980.

5. Sovago I, Kiss T, Gergely A. Critical survey of the stability constants of complexes of aliphatic amino acids, Pure Appl. Chem. 1993; 65:10291080.

6. Taha M, Khalil MM. Mixed-ligand complex formation equilibria of cobalt (II), nickel (II), and copper (II) with N, N-bis (2-hydroxyethyl) glycine (bicine) and some amino acid. J. Chem. Eng. Data 2005;50(1):157-163.

7. Bastug AA, Goz SE, Talman, Yesim, Gokturk S, Asil E, Caliskan, EJ Coord. Chem. 2011;64: 281-92.

8. Perkins DJ. A study of the effect of amino acid structure on the stabilities of the complexes formed with metals of group II of the periodic classification. Biochem J.1953;55(4):649-652.

9. Martell AE, Smith RM. Critical Stability Constants of Amino Acids. Plenum, New York. 1974.

10. Martell AE. Critical Stability Constants of Metal complexes: Plenum Press. New Yor. 2006;26.

11. Smith RM, Motekaitis RJ, Martell AE. Prediction of stability constants. II. Metal chelates of natural alkyl amino acids and their synthetic analogs. Inorg Chim Acta. 1985;103(1):73-82.

12. Masoud MS, Abdel-Nabby BA. The behavior of some cobalt, nickel and copper amino acid complexes at different temperatures. Thermochim Acta. 1988;128:75-80.

13. Casale A, De Robertis A, De Stefano C, Gianguzza A, Patane G, Riango $\mathrm{C}$, et al. Thermodynamic parameters for the formation of glycine complexes with magnesium (II), calcium (II), lead(II), manganese (II) at different temperatures and ionic strengths with particular reference to natural fluid conditions. Thermochim Acta 1995, 255:109-41.

14. Shoukry MM, Shehata MR, Mohamed MMA. Binary and ternary 
complexes of Cd (II) involving triethylenetetramine and selected amino acids and DNA units. Mikrochim Acta. 1998;129(1):107-113.

15. Iqbal MZ, KhurshidS, IqbalMS. Antibacterial activity of copper-amino acid complexes. J Pak Med Assoc. 1990;40(9):221-2.

16. Dogan A, KoseogluF, Kilic E. The stability constants of copper (II) complexes with some $\alpha$-amino acids in dioxane-water mixtures. Anal Biochem. 2001;295(2):237-9.

17. Rani RS, Rao GN. Stability of binary complexes of L-aspartic acid in dioxane-water mixtures. Bull. Chem.Soc. Ethiop. 2013;27(3):367-376.

18. Demirelli H, Koseoglue F. Equilibrium studies of Schiff bases and their complexes with Ni (II), Cu (II), and Zn (II) derived from salicyldehyde and some $\alpha$-amino acids. J Solu Chem. 2005;34(5): 561-577.

19. Mohamed AA, Bakr MF, Abd El-Fattah KA. Thermodynamic studies on the interaction between some amino acids with some rare earth metal ions in aqueous solutions. Thermochim Acta. 2003;405(2):235-253.

20. Sajadi SAA. Metal ion-binding properties of L- glutamic acid andLaspartic acid, a comparative investigation. Natural Sci. 2010;2(2):8590.
21. Pettit LD. Critical survey of formation constants of complexes of histidine, phenylalanine, tyrosine, L-DOPA and tryptophan. Pure Appl. Chem. 1984;56(2): 247-292.

22. Fazary AE, Mohamed AF, Lebedeva NS. Protonation equilibria studies of the standard $\alpha$-amino acids in $\mathrm{NaNO}$ solutions in water and in mixtures of water and dioxane. J. Chem.Thermodyn. 2006;38(11):1467-1473.

23. Turkel N. Stability constants of mixed ligand complexes of Ni (II) with adenine and some amino acids. Bioinorg. Chem. Appl. 2015:1-9. doi. org $/ 10.1155 / 2015 / 374782$

24. Choi TB, Pardridge WM. Phenylalanine transport at the human blood brain barrier: Studies with isolated human brain capillaries. J Biol Chem. 1986;261(4): 6536-6541.

25. Chalmers RA, Chemistry of Complex equilibria: Van Nostrand Reinhold Company. London. UK. 1970.

26. Irving HM, Williams RJP. Stability of Transition Metal Complexes J. Chem. Soc. 1953:3192-3210. doi: 10.1039/JR9530003192 